\title{
Kant'in Ruhun Ölümsüzlüğüne İlişkin Görüşlere Yönelik Eleştirileri ve Phaidon Diyaloğundan Hareketle Platon'un Bu Eleştirelere Verebileceği Olası Cevaplar
}

DOI: $10.26466 /$ opus.586864

\author{
* \\ Ahmet Uğurlu* \\ * Dr. Öğrt. Üyesi, Bolu Abant İzzet Baysal Üniversitesi İlahiyat Fakültesi, Bolu/Türkiye \\ E-Posta: dusunurugurlu@hotmail.com \\ ORCID: 0000-0002-6983-7891
}

\begin{abstract}
Öz
Kant'ın, kendisinden sonraki düşüncede eskisine nazaran önemli bir değişimi gerçekleştirdiği söylenebilir. Bu değişimin kaynağında Kant'ın, klasik metafiziğin ruhun varlı̆̆ını ortaya konulabileceği ve ruh üzerinden insani tecrübenin açıklanabileceği yaklaşımını eleştirmesi, ruhun bir töz olarak varlı̆̆ı iddia edilmeden de insan tecrübesinin açıklanabileceği ve bilimlerin temellendirilebileceğini savunmasının var olduğunu söylemek mümkündür. Ona göre duyusal tecrübenin kuruluşundan bahsedilebilmesi için düşünülürlerin (Noeta) varlı̆̆ın savunmaya gerek yoktur. Oysa Platon'a göre duyusal dünyanın açıklanması için düşünülürlerin varlı̆̆ından hareket edilmesi gerekir. Bu nedenle de Platon, düşünürleri var kabul ederek ruhun varlğ̆ına ve ölümsüzlü̆̆̈̈ne de delil olarak göstermeye çalışır.Platon ruhun ölümsüzlüğünü savunmak için Phaidon adl eserinde birçok kanıt ileri sürmektedir. Kant'ın ampirik nesnenin kuruluşuna dair yaklaşımı dikkate alındığında Phaidon'da ruhun ölümsüzlüğ̈̈ ilgili var olan kanıtlar ne şekilde ele alınabilir? Ya da Phaidon adl eserde ortaya konulan delilleri Kant'ın eleştirilerine bir cevap olarak görmek mümkün müdür? Phaidon'daki Kebes adlı şahsın ruhun ölümsüzlüğ̈̈ne yönelik itirazlarının Kant'ın ruhu bir töz olarak kabul etmeye yönelik eleştirilerini anımsattı̆̆g söylenebilir mi? Bu çalışmada Platon'un Kebes'e cevapları Kant'ın eleştirileri dikkate alınarak tartışılmaktadır
\end{abstract}

Anahtar Kelimeler: Kant, Platon, Phaidon, Ruh, Kebes, 


\title{
Kant's Criticism of The Claims Concerning The Immortality of Soul and Plato's Probable Answers in Phaidon
}

\begin{abstract}
It can be said that Kant, in comparison to his predecessors, has caused a more significant change in the course of philosophical enterprise. It is possible to say that Kant achieves such an impact by explaining human experience and providing foundations for natural sciences after denying the existence of soul as substance as classical metaphysics defends. According to him, there is no need to defend the existence of intelligible in themselves to constitute empirical experience. However, according to Plato, in order to explain the sensory world, it is necessary to move from the existence of intelligible. For this reason, Plato tries portray intelligible as evidence for the existence and immortality of the soul. Plato suggests a number of arguments in his Phaidon to defend the immortality of the soul. How can we evaluate Plato's arguments in Phaidon in view of Kant's view of the constitution of the empirical objects? Can it be claimed that Kebes' objections against accepting soul as a substance anticipate those of Kant's concerning the immortality of the soul? In this study, Plato's answers to Kebes are discussed by keeping Kant's criticisms in mind.
\end{abstract}

Keywords: Kant, Plato, Phaidon, Soul, Kebes, 


\section{Giriş}

Kant amprik nesnenin (Gegenstand) ${ }^{1}$ kuruluşuna dair yeni bir felsefi zemin kurabilmek için daha önce var olan metafiziksel yaklaşımı eleştirme ihtiyacı duymuştur. Ona göre Newton fiziğinin felsefi temelinin inşa edilebilmesi için klasik metafiziğin üzerine temellendiği felsefi anlayışın eleştirilmesi gerekmektedir. Bu da ancak hem duyusal olarak kendisine temas edilen nesnenin kuruluş zeminin hem de fizik yasalarının geçerliğinin zeminini bir araya getirecek bir felsefi yaklaşımla savunulabilir. Newton fiziği doğa hakkında genel geçer yasalar ortaya koymuş olmasına rağmen hakkında yargılar verilen ve muhakemeye konu olan nesnelerin varlığ 1 ve kuruluşu hakkında felsefi olarak sorunlara kaynaklık etmiştir (Friedman, 1992, s. 1). Newton fiziğine uygun bir şekilde nesnenin kuruluşundan bahsedilebilmesi için zamanda ortaya çıkanları zamanın kurallarına uygun bir şekilde bir arada tutulabilmesinin imkânı hakkında felsefi bir açiklama yapması gerekmektedir (Çitil, 2012, s. 54). Zaman ile zamanda ortaya çıkanın bir araya getirilebilmesi de ancak kendinde olanların (noeta) varlığını reddetmeyi gerektirir. Çünkü ona göre kendinde olanın (ding an sich) zamanda ortaya çıkması düşünülemeyeceği için zamanda olanın ruhsal bir alanla ilişkisinden bahsedilemez. Oysa klasik metafiziğin nesne kuramının temelinde ruhun fiziksel dünyadan bağımsız kendinde bir varlığı olduğu yaklaşımı bulunmaktadır. Ayrıca ruhsal varlık alanı ile duyusal dünya arasında da tek taraflı bir ilişki olduğu fikri hakimdir. Yani ruhsal varlık alanı duyusal nesnenin mevcudiyet kazanmasında belirleyici bir role sahiptir. Bu yaklaşım en temelde Platon'un Phaidon adlı eserde savunduğu ruhun ölümden sonra da yok olmadığı fikrinden beslendiği düşünüldügüüde Kant'ın eleştirilerinin muhatabı olarak Platon'u görmek mümkündür. Bu nedenle Platon'un ruh teorisinin Kant'ın eleştirileri bağlamında ele alınması ve tartışılması önem arz etmektedir.

\footnotetext{
${ }^{1}$ Kant saf nesne (object) ile amprik nesne (gegenstand) arasında ayrım yapmaktadır. Kant genel itibari nesneden bahsederken object kavramını kullanır. Fakat eğer duyusal temsillerin sentezlenmesi sonucu kurulan nesneden bahsediyorsa amprik nesne (gegenstand) terimini kullanir. Kant duyusal temsiller olmaksızın da kurulabilen nesnelerden bahsetmektedir. Örneğin matematiksel nesneler duyusal temsillerden bağımsız varlığından bahsedilemezse de kurulması için amprik temsillere ihtiyaç duyulmaz (Çitil, 2012, s. 24).
} 
Platon'un Phaidon adlı eserinde Sokrates kendisini ziyarete gelen öğrencilerine ruhun duyusal nesnelerde var olmayan bir kalıcllı̆a sahip olduğunu göstermeye çalışmaktadır. Phaidon adlı eserden anlaşıldığ1 üzere Sokrates gençlerin ahlakını bozma suçlamasıyla ölümle cezalandırılmıştır. Bu cezasının infazını beklerken öğrencileri ve dostları tarafından ziyaret edilir ve onların arasında ruhun kalıcılığının nasıl anlaşılması gerektiği noktasında bir tartışma zuhur eder. Üzüntüsünü paylaşmak niyeti ile kendisini ziyarete gelen öğrenciler, Sokrates'in yüzündeki mutluluğu görünce şaşırırlar. Böyle bir durumda genellikle insanların üzüntülü olması gerektiği düşüncesinden dolayı Sokrates'ın neden bu kadar rahat ve mutlu olduğunu merak ederler. Sokrates daha yüce dostların olduğu bir yere gideceği için mutlu olduğunu ifade eder. $\mathrm{Bu}$ da beraberinde ruhun ölümden sonra bir kalıcılığının olup olmadığ 1 tartışmasina sebep olur.

Sokrates'i ziyarete gelmiş olanlardan Simmias ve Kepes'in soruları daha çok ön plana çıkar. Ölümle cezalandırılan Sokrates'in ölmekten dolayı mutlu olmasını intihar edenlere yönelik fikirlerinden dolayı tutarlı olmadığını öncelikle iddia ederler. Eğer ölüm daha iyi bir yere gitmek ise insanın kendi eli ile hayatına son vermesinin neden kötü olduğu sorusu tartış1ır (Platon, 2015, s. 62). Sokrates hayatın kişiye tanrı tarafından verilen bir lütuf olduğunu ve hayatına kendi eliyle son verilmesinden tanrının hoşlanmayacağı önermesinden hareketle intiharın kabul edilebilir olmadığını savunur. Kişinin kendi kararı olmaksızın gelen ölümü cesaret ve soğukkanlılıkla karşılamalı ve ölümden sonraki yaşamda sohbet edeceği dostların varlığı ile mutlu olmayı bilmelidir. Bundan sonra eli ile gerçekleşmesi doğru olmamasına rağmen felsefecinin ölümü neden arzuladığı ve ölüme karşı tavrının diğer insanlardan neden farklı olması gerektiği tartışılır. Ayrıca Sokrates bedene ait olan şeylerin peşine düşmesinin filozofa yakışmayacağını iddia eder. Bedensel arzuların felsefecinin peşine düştüğü erdemler için engel arz ettiğini söyler. Bu nedenle de filozof eğer gerçekten erdemli ve bilge bir duruma ulaşmak istiyorsa ruhun bedenden tamamen koptuğu bir hayata inanmalı ve onu arzu etmelidir. Filozof bedenin arzularından kopmaya çabalıyorsa peşine düşeceği şeylerin kaynă̆ında geriye ihtimal olarak ruh kalır. Ayrıca filozof eğer gerçek bilgiyi arzuluyorsa bedenin bunu sağlama imkânı bulunmamaktadır. Çünkü beden insanı duyulur alana yöneltir ki duyulur 
alan gerçek bilgelik için zemin olamaz. O halde gerçek bilgi ancak ruhun görüsü ile sağlanabilir.

- Simmias lafa karıştı ve şöyle dedi: “Sokrates! Bence bu kez Kebes'in söyledikleri doğru. Gerçekten bilge olan insanlar neden kendilerinden daha akıllı olan efendilerinden kaçsinlar, neden onlardan uzak durmak istesinler? Bizden ve yetkin tanrilardan uzaklaşmak için, Kebes'in söyledikleri doğru.

- Sokrates: Haklısınız, tıpkı mahkemede olduğu gibi burada da savunma yapmam gerektiğini bana hatırlatıyorsunuz.

- Simmias: Evet, bunu istiyoruz.

- Sokrates: Tamam, madem istiyorsunuz öyle olsun. Mahkemede yaptığımdan daha iyi bir savunma yapacağım. Simmias! Kebes! Ĕ̆er öteki dünyada burada olanlardan daha akull insan ve tanriları göreceğime inanamasaydım, ölüme kızmamakla haksızlık yapmış olurdum. Ancak bu insanlarla kısa sürede görüşmek umudumda olduğuma emin olun. Lakin yetkin tanrıları orda göreceğimden eminim. Her şeyden daha çok bunu bekliyorum. Bu nedenle ölümden korkmuyorum, çünkü ölümden sonra yaşamın olduğuna inanıyorum. Ayrica eski inançlara göre, bu durum kötülerden daha çok iyilere yarayacaktır (Platon, 2015, s. 50-51).

Platon'un ruhun ölümlü olmadığına dair önemli bir kanıtı anamnesis kuramıdır. Ona göre bilgeliğin üzerine temellendiği zemin olan değişmeyen doğalar duyusal alem aracılığ 1 ile elde edilemezler. Duyusal dünya sürekli karşıtına dönüşme ve farklılaşma özelliğine sahip olması nedeniyle değişmeyen hakikatleri kendi içerisinde barındıramazlar (Temizkan, 2016, s. 218). Eğer ruh ölümsüz olmasaydı zamana tabi olmayan bu gerçekliğin bilgisine ulaşamazdı. Zamanda ortaya çıkan karşıtlıklar ve bunların birbirinin yerini alması zamanda var olmayan kendinde gerçekliğin olduğu Hades'e bağlıdır. Ona göre bu nedenle gerçek bilginin elde edilebilme zemini anamnesis kuramına dayanmaktadır ki bu kuramda ruhun zamana tabi olmayan bir kalıcılığının olduğunu gösterir (Platon, 2015, s. 56).

Metnin ilerleyen kısımlarında Simmias, söylenenlerin ruhun bedenden ayrı bir varlık olduğuna delil olarak görülemeyeceğini söyler. Ona göre sazın telleri sazı meydana getiren parçaları için ne ifade ediyorsa ruh da beden için odur. Yani sazın parçaları ve telleri arasındaki uyum sazı ve işlevini nasıl meydana getiriyorsa ruh da beden için o tür bir fonksiyon 
ifade etmektedir. Sazdaki uyumluluk nasıl saza bağlı ise ruhun varlığı da o şekilde bedene bağlıdır. Ruhu bedende var olan unsurları bir arada tutan bir uyumluluk olarak görmek daha doğrudur. Bu uyumluluk bozulduğunda ruhun bedenden bağımsız bir varlığını iddia etmek anlamlı değildir. Yani aslında asıl olan maddi unsurlardır. Ruh ve canlılık gibi şeyler de maddi unsurların bir araya gelişinden ortaya çıarlar. Sokrates'in ilk cevabı ya da eleştirisi anamnesisi kabul eden Simmias'ın bunu söylemesinin tutarlı olamayacağını göstermeye yöneliktir. Sokrates'a göre anamnesis kuramı doğru kabul edildiğinde ruhun bedenin parçalarının bir araya gelmesi ile açıklanamayacağının kabul edilmesi gerekmektedir. Duyusal dünyada var olmayan gerçekliklerin hatırlanabilmesi için ruhun bedende var olmadan önce bunları biliyor olması gerekir. Çünkü bunlar bedenle birlikte öğrenilecek şeyler değildirler. Duyusal dünyada bunlara karşılık gelen şeyler, anamnesis ile hatırlananları tam olarak temsil etmezler (Platon, 2015, s. 55-56). Bu nedenle de anamnesis kuramı duyuda var olmayan gerçekliklerin nasıl bilindiğine dair bir çözüm olduğu düşünüldüğünde bedenle sinırlı bir varlık tarafından bunların beden sahibi olmadan önce nasıl öğrenildiğine dair bir açıklama vermez.

Sokrates'e göre ruhların arasında erdemli ve erdemsiz ayrımının var olduğu dikkate alındığında ruhu sazın tellerindeki uyum ve ahenk gibi ele almak kabul edilemez. Ona göre sazın telleri ile ilgili olarak daha az ahenkli ya da daha çok ahenkli türünden bir ayrım yapılması doğru değildir. Ayrıca ruhun bedenin isteklerine de direnebildiği dikkate alındığında ruhun ahenk gibi ele alınamayacağı anlaşılır. Yani sazın tellerindeki ahenk hiçbir şekilde tabi olduğu parçaların gerektiğinden farklı bir işlev yerine getiremezler. Oysa ruh hem bedeni yönetmekte hem de bedenin arzu ve taleplerine karşı gelebilmektedir. Bu da ancak ruhun bedenden bağımsız bir varlığa sahip olduğunun gösterilmesi ile açıklanabilir.

Simmias'ın itirazından sonra bu çalışmada ön plana çıkacak olan yaklaşım olan Kebes'in eleştirileri gelir. Ona göre anamnesis kuramı kabul edilmesine bağlı olarak ruhun bedene ait olduğu düşünülmese de yine de ruhun ölümlülüğü savunulabilir. Ona göre ruh bedenden önce var olabilir ve kalıcılık olarak da bedenden daha güçlü olabilir. Fakat buna rağmen belli bir süre sonra yok oluşa tabi olmadığı anlamına gelmez. Kebes bir dokumacı örneğinden yola çıkarak fikrinin doğruluğunu göstermeye 
çalışır. Ona göre ruhun bedenden sonra varlığını iddia etmek dokumacının dokuduğu elbiselerinin varlığından yola çıkarak "dokumacı halen yaşıyor" demek gibidir. Dokumacı birçok elbise eskitebilir ve en son elbiseyi eskitmeden ölebilir. Buradan yola çıkarak bedenin ruhtan daha kalıcı ve güçlü olduğunun söylenmesi doğru olmadığ gibi birçok elbiseyi eskittikten sonra ölümü mümkün olabileceği için de ruhun hiçbir şekilde ölmediğini iddia etmek de doğru değildir. Ruhun bedenden öncelikli olduğu anamnesis kuramından yola çıkarak kanıtlanabilir. Fakat buradan ruhun hiçbir şekilde ölümsüz olduğu kanitlanamaz.

Kebes: Benim daha önce söylediğim benzer konularda itirazım devam ediyor. Ruhumuzun bedene girmeden önce var olduğ u konusuna karşı çıkmıyorum. Bana kalırsa, bu çok başarılı şekilde ispatlandı. Ancak benim itirazım, ruhun biz öldükten sonra var olmaya devam ettiği noktasında. Öte yandan, Simmias'ın söylediği şeye, bedenin ruhtan daha güçlü olduğu inancına katılmıyorum. Çünkü bence burada üstün olan taraf ruhtur. Tabi şöyle de denebilir: neden ölümden sonra insanın en zayıf noktası olan beden varlığını hala sürdürürken, sen buna inanmıyorusun? En dayanaklı parçanın varlığına aymı zamanda var olduğuna neden inanmıyorsun. Bu soruyu nasıl yanıtladığıma bir bak. Simmias gibi ben de bir karşılaştırma yapacă̆ım. Bence bunu söylemek, ölmüş dokumacı biri hakkında "o ölmedi! Halen bir yerlerde yaşıyor" demek gibi bir şeydir. Bu noktada ispat için dokumactnın giydiği elbisenin ya da dokuduğu şeylerin sağlam olduğu söylenir ve bunlarm yok olmadığı gösterilir. Bir insan bu düşünmeye inanamaz ve sürekli var olanın insan mı yoksa onun kullandı̆̆ı bir şey ya da giydiği elbise mi sorulduğunda, sürekli var olanın insan olduğu söylenince, bunun insanın yaşamasının bir ispatı olduğu düşünülür. Çünkü kendisinden daha az sürekli olan hiçbir zaman yok olamamaktadır. Simmias! Bana kalırsa bunlar doğru değil. Söyleyeceklerime dikkat et. Gerçekten de herkes bu düşüncenin saçmalı̆ııı anlayabilir. Çünkü dokumacı dokuduğu bütün elbiseleri eskittikten sonra ölür, ama yine de son dokuduğu elbiseyi eskitmemiştir. Bu nedenle insan elbiseden daha az dayanıklı ya da daha aşağıda değildir. Bu düşünceyi beden ruh ilişkisine de uyarlayabiliriz. Ruh uzun süre var olur, beden ise daha zayftır ve onun sürekliliğ $i$ daha zayıftır. Öte yandan ruh yok olduğu zaman, beden hemen zayıflar ve çürüyüp yok olur (Platon, 2015, s. 78).

Kebes'in itirazlarının, bedene canlılık veren ruhun duyusal dünyadan bağımsız bir varlığı olmadığı düşüncesine sahip olan Kant'ın düşüncesini anımsattığı söylenebilir. Kant'a göre canlılık duyusal dünyadan bağımsız 
bir varlık alanına ait olarak görülemez. Canlılık harekete tabi olması nedeni ile zamandaki değişime açık bir yapıdadır. Bu yüzden de canlılığın hareket aracılığı ile var olmadığı ve kendinde varlık alanı aracilığı ile bedende bulunduğunu söylemek doğru değildir. Çünkü Kant'a göre duyusal nesne nasıl ki belli bir büyüklüğe sahipse canlılı̆̆ın da bir büyüklüğünün olduğu söylenebilir. Duyusal nesnenin büyüklüğünün süreç içerisinde yok olması gibi canlılığın da zamanla aşamalı bir şekilde bu büyüklüğünü kaybettiği söylenebilir. Bu itibarla Kant, Platon'un canlılığın, hareketin olmadığı kendinde bir varlık alanına ait olduğu fikrini kabul etmez. Bilakis aynı Kebes gibi ruhun ya da canlılığın her ne kadar beden kadar olmasa da harekete ve değişime tabi olduğu ve bu nedenle de yok olmaya ya da bozulmaya uğrayacağı fikrine sahiptir. Kant'ın bu yaklaşımının temelinde düşünce aracılığı ile temas edilen sayı ya da nesnelerin mahiyetinin kendinde bir varlık alanına ait olmadığı, bilakis insanda var olan belli yetiler aracılığı ile kurulduğu fikri bulunmaktadır. Ona göre klasik metafizik düşüncesinde bunlar bilincin inşa sürecinden bağımsız kendinde nesneler olarak görülmekte ve "mutlak bir"in amprik nesneye temasını bunlar tarafından sağlandığı düşünülmekteydi. Kant'ın bu yaklaşımı eleştirmesi üzerinden transandantal idealizm düşüncesini inşa ettiği düşünülürse klasik metafiziğin nihai kökeni olan Platon düşüncesi üzerinden Kant'ın yaklaşımını değerlendirmek anlamlı hale gelir (Kant, 1993, s. B414).

\section{Kant'ın Ruhun Ölümsüzlüğü Düşüncesine Eleştirisi}

Kant o döneme hakim olan bilimin klasik metafiziğin yanılsamalarından kurtarılması gerektiğini düşünür. Ona göre metafizik, tarih boyunca hiçbir şekilde sonuç alınamayan yoğun bir tartışma alanı olmuştur. Ayrıca da bu yoğun tartışmalara rağmen de herhangi bir ilerleme kaydedilebilmiş değildir. Ona göre metafiziğin bir türlü sonuç alamadığı konularından biri de canlılığa kaynaklık eden ruhun varlığıdır. Kant, ruhun varlığına dair önceki yaklaşımların içine düştüğü yanılsamanın, "düşünüyorum" yargısının bütün kavramların ve yargıların taşıyıcısı olması nedeni ile ona bir varlık atfedilmesinden kaynaklandığını düşünür. "Düşünüyorum" yargısına bağlı olarak var olan kavramların ve yargıların taşıyıcı öznesi olması gerektiği fikrinden hareketle ruhun varlığına ya da 
öznenin kalıcılığına ulaşıldığını düşünen Kant, bunun ruhun zamandan bağımsız bir varlığı olduğu fikrine kaynaklık ettiğini düşünür (Kant, 1993, s. A341). Ona göre "düşünüyorum" yargısı düşüncenin içeriği olan kavram ve yargıların taşıyıcısı olması nedeniyle aşkınsal olarak görülmelidir. $\mathrm{Bu}$ nedenle düşünüyorum ile ilgili bütün yargilar ve çıkarımlar aşkınsal bir nesne hakkında olmak durumundadır. Ayrıca ona göre ruh kavramının içsel duyumun nesnesi olması nedeniyle dış duyumda ortaya çıkandan farklı olduğu fikri de ruhun varlığına ve bilinebileceğine işaret olarak kabul edilmiştir. Dış duyumun nesnesi olanın iç duyumda ortaya çıkandan farklı olduğu ruha dair yaklaşıma temel bir zemin sağlamıştır. Yani iç duyu nesnesinin diş duyu nesnesinden farklı olduğu fikri ruhun var olduğu yaklaşımı için dayanak olarak kabul edilmiştir (Kant, 1993, s. B401).

Kant'a göre kategoriler üzerinden aşkınsal nesnelere belli yüklemlemelerde bulunmalar şu şekilde gerçekleşir:

Tasarımı yargılarımızın saltık öznesi olan ve buna göre bir başka şeyin belirlenimi olarak kullanılmayan kendilik tözdür. Ben, düşünen bir varlı, tüm olanaklı yargılarımın saltık öznesiyimdir, ve benim kendime ilişkin bu tasarım başka herhangi bir şeyin yüklemi olarak kullanilamaz. Öyleyse ben, düşünen varlık (ruh) olarak, tözümdür (Kant, 1993, s. A349).

Kant, saf kavramların amprik temsiller haricinde kullanımının geçersiz olduğunu düşündüğü için bu çıarımın yanılsama ürettiğini ifade eder. ${ }^{2}$ Ona göre töz kategorisi hissetme yetisinde ortaya çıkan amprik temsillerin, kalıcı olan bir özneye ait kılınarak düşünülmesini sağladığı için duyusal dünya haricinde kullanımı geçersizdir. (Hanna, 2001, pp.106) Ona göre bu kategoriler, amprik temsiller olmaksızın boş ve içeriksiz işlevlerdir. Bu kategorilerin mantıksal analizi üzerinden herhangi aşkınsal bir nesnenin kalıcılığından bahsetmek mümkün değildir. Ona göre töz kategorisi amprik temsillerin bulunduğu alanda zamanda kalıı bir şeylerin farkındalığına kaynaklık eder. Zamanda olanı zamanın kendisinden ayırırız. Değişimde olanın farkındalığını zamanın kendisis-

\footnotetext{
${ }^{2}$ Kant yanılsamayı schein ile ifade eder. Ona göre duyusal nesnelerin bilinmesinin zemininde olan kategorileri hakkında herhangi bir şekilde temsiller edinemediğimiz aşkınsal (transandant) nesneler hakkında da kullanıldığında içine düşülen duruma schein denir. Schein herhangi bir şekilde bir bilgi kaynağına sahip olmadığımız aşkınsal nesneler hakkında bilgimiz varmışçasına hükümlerde bulunmaktır.
} 
inin bilincinden ayırdığımızda töz kategorisi ortaya çıar. Ona göre amprik nesnenin kurulup karşıma konulabilmesi için değişenin altında sürekli aynı kalanın bilincinde olmak lazım. Zamanın bilincinde olmak ile ilgili olan bu saf kavramın zamanın dışında bir kullanımının geçersiz olduğunu düşünür (Melnick, 2009, s. 133).

Kendisinin değişik zamanlardaki sayısal özdeşliğinin bilincinde olan biri, bu düzeye dek kişidir.

Ruh ...dir vb.

Öyleyse kişidir (Kant, 1993, s. A352).

Nesnenin zamandaki özdeşliği düşünenin kendisinin farkında olmasının sayısal özdeşliğine bağlıdır. Nesneyi özdeş olarak bilebilmem için zamandaki sayısal özdeşliğinin farkında olmam gerekir. Amprik temsillerden gelmeyen nesneye ait bu birlik düşünenin zamandaki özdeşliğinin bilincinden gelmektedir. Kant nesneye süreklilik veren kendinlik bilincine olana ait bu sayısal özdeşlik "ben" in bir töz olması için yeterli bir zemin olmadığını düşünür. Ya da bu sayısal özdeşlikten kaynaklı sürekliliğin varlığından yola çıkılarak ruhun zamandan bağımsız bir kalıcılığının olduğu fikrine ulaşılamaz. Çünkü nesnenin ayniyetinin kaynağındaki bu sayısal özdeşlik, bilincin zamanın farkındalığının birliği olsa da ruha varlık atfetmek için yeterli bir zemin olarak görülemez. Zamanı birlik içinde tutan bilincin birliği ruhun bir töz olarak görülebilmesi için yeterli bir zemin olmadığını düşünen Kant'a göre kendinlik bilincinin, nesneyi kurmak için gerekli bir zemin olma dışında bir varlığı söz konusu değildir.

Dış varlı̆̆ yalnızca verili alğların nedeni olarak çıkarsanabilenin yalnızca ikircimli bir varoluşu vardır.

Şimdi tüm dış görüngüler öyle bir yapıdadır ki, dış varlıkları dolaysızca algılanamaz ve onların varlığı verili algıların nedeni olarak çıkarsayabiliriz.

Öyleyse dış duyunun tüm nesnelerinin dış varlı̆̆ı ikircimlidir (Kant, 1993, s. A362).

İç duyunun nesnesi olan ruhun gerçekliği amprik temsillere kaynaklık eden maddi tözün belirsizliği üzerine kurulmuştur. İç duyu ile dış duyu arasında ne kadar farklılık görülebilse ve dış duyumun kaynağında olanın maddi bir töz olduğu ortaya konabilse ruh hakkında da kesin bilgiye ulaşılabileceği düşüncesi hakim olmuştur. Diş duyunun kaynağındaki nesnenin varlığının bilgisine iç duyusal tecrübe üzerinden ulaşılabileceği 
düşünüldüğü için dış amprik temsillerin kaynağındaki nesnenin varlığından ve gerçek oluşundan şüphe edilmiştir. Kant'a göre diş duyunun kaynağındaki nesnenin tam bir bilgisine ulaşmadan böyle bir ayırım yapmak kabul edilemez. Çünkü dış duyum denilen şey de dış duyumun kaynağında var olan mekan da bir tasarım olarak bulunur. Uzayın ve amprik nesnenin bilinçte ortaya çıkan tasarımlar olduğu düşünüldügünde içsel histe ortaya çıanı diş duyumun kaynağında var olanla ayrıştırmanın geçersiz olduğu söylenebilir. Kant'a göre içsel histe olanı dış duyum ile ayrımanın temelinde duyusal temsillerin kendisine ait kılınan ampirik nesnenin kendinde bir varlığı olduğu fikrine dayanır. Oysa amprik temsiller hissetme yetisinde ortaya çıkarlar ve hissetme yetisinin dışında bunların nasıl bir varlıklarının olduğun bilmek mümkün değildir (Kant, 1993, s. A374).

Kant felsefesini yeni bir nesne anlayışı üzerinden ortaya koymaktadır. Kant' a göre duyusal olarak temas edilen nesnenin bizatihi varlığına temas edilemez. Nesnenin var olması ve onun hakkında yargılarda bulunabilmek için inşa sürecine tabi tutulması lazım. Nesnenin inşa edilebilmesi için amprik bir malzeme ve bilincin bu malzemeye atfettiği bir form olması gerekir. Platona'a göre de nesnenin karşımızda varlığı bizatihi olmadığı için açıklanmaya ihtiyaç duyar. Platon nesnenin kuruluşunda transandant bir fiilin olduğunu ve bu fiilin açıklanmasını felsefeye ait faaliyet olarak görürken, Kant amprik nesnenin kuruluşunu Appercetion (tam algi) fiiline tabi olarak açılamaktadır. (Dickerson, 2004, s.88) Bu nedenle her iki düşünürün de nesnenin nasıl olup da var olduğu ve hakkında dil üzerinden anlamlı önermelerin mümkün olduğuna dair bir nesne kuramlarının olduğu söylenebilir (Kant, 1993, s. A146).

Kant, klasik metafiziğin sınırları içerisinde düşünmekten kaynaklı birçok problemin çözülebilmesi için nihai anlamda kaynağ 1 Platon'a kadar giden aposteriori nesne kuramının eleştirilmesi gerektiğini ve yeni bir nesne ve bilgi kuramının geliştirilmesi gerektiğini düşünür. Kant temelde kaynağı Platon olan nesne kuramının zemininde bilincin kurucu faaliyetinden bağımsız varlığa sahip olan düşünülürlerin (noeta) olduğunu iddia eder. $\mathrm{O}$, kendinde varlığ olan düşünsel nesnelerin amprik nesnelerin kuruluşunda işlev gördükleri ve bunların varlığının bire bağlı olduğu fikri ve insan düşünme tecrübesi içerisinde bir ile bağının olabileceği yaklaşımın klasik metafiziğin problemlerinin kaynağında olduğunu düşünür. 
Kant'a göre sonuç alınamayan metafizik tartışmalardan bilimin kurtulabilmesi için amprik nesnenin varlığının zemininde düşünülür nesnelerden bağımsız bir yapının var olduğunun gösterilmesi gerekmektedir.

Kant'in Platon'dan beri var olagelen ve en son olarak da Leibniz'de varlığını gösteren metafiziğe yönelik eleştirisi, zamanın ve amprik nesnenin zamanla ilişkisinin nasıl anlaşılması gerektiği noktasında yoğunlaşmaktadır. Platon'a göre zaman sayıların ardışıklığı içerisinde Demiurgos'un canlandırma faaliyeti aracılığıyla var iken Kant zamanın öznenin duyulmama formu olduğunu ve bu nedenle de sayının varlığının duyumlama formu olan zaman ve mekana bağlı olarak inşa edildiğini düşünür. Duyulmamada ortaya çıkan temsillerin sayı ve kategoriler aracılığı ile nesneye dönüştürülme sürecinin açıklamasını veren Kant amprik nesnenin kuruluşu için herhangi bir şekilde zamandan bağımsız olan ve düşüncede temas edilen noeta'ya gerek olmadığını ileri sürer. Dolayısıyla, Kant'ın ruhun ölümsüzlüğüne ilişkin yukarıda ifade ettiğimiz eleştirilerinin zemini düşünürlerin (noeton) varlığı kabul edilmeden de amprik nesnenin kuruluşunun ortaya konulabileceği fikrine dayanmaktadir.

Kant'a göre amprik nesne kurulup bilince konu edilebilmesi için malzeme olarak amprik temsillere ihtiyaç duyulsa da amprik malzemenin amprik nesneye dönüşebilmesi için öznenin kurucu ve düzenleyici rolüne ihtiyaç bulunmaktadır (Longuenesse, 2000, s. 17). Bu nedenle de o, ruhun yetilerinin bir teşrihini yapmak durumunda kalmaktadır. Kant'a göre amprik nesnenin kuruluşunda üç öznel yeti birlikte devrededirler. Amprik malzemenin nesne olarak idrak edilebilmesinin temelinde, temsillerin tezahürünün zemininde olan hissetme yetisi, bu temsilleri zaman ve mekan formuna göre yeniden üreten muhayyile yetisi ve muhayyile yetisinin yeniden ürettiklerine birlik kazandıran tam alg1 (Apperzeption) yetileri bulunmaktadır (Brook, 1994, s. 25). Kant'a göre nesnenin belli birlik halinde tutulabilmesi için bu yetilerin üçünün ortak bir şekilde hareket etmesi gerekmektedir. Bu yetilerin her birinin kendisine ait bir işlevi bulunsa da nesnenin kuruluşu bu üç yetinin ortaklaşa faaliyetine bağlı olarak gerçekleşmektedir (Guyer, 1987, s. 49).

Ĕ̆ger her bir tasarım başkaları ile bütünü ile yabancı ve bir bakıma yalıtılmış ve onlardan ayrılmış olsaydı, hiçbir zaman bilgi gibi bir şey ortaya çıkmazdı- bilgi ki, karşılaştırılan ve bağlantılanan tasarımların bir bütünüdür. Duyu kendi 
sezgisinde bir çokluk kapsadığı için, ona bir synopsis yüklüyorum. Ama böyle bir synopsise her zaman bir sentez karşılık düşmelidir; ve alıcllık ancak kendiliğindenlikle birleştiğinde bilgiyi olanaklı kllabilir. Şimdi, kendiliğindelik tüm bilgide zorunlu bir yolda bulunan üçlü bir sentezin zeminidir. Anlığın sezgideki değişkileri olarak tasarımlarm ayrumsanması, bunların imgelemde yeniden üretilmeleri, ve bir kavramda tanmmaları. Bunlar üç öznel bilgi kaynă̆ın gösterirler ki, anlağın kendisini ve, onun yoluyla, onun görgül bir ürünü olarak tüm deneyimi olanaklı kılarlar (Kant, 1993, s. A98).

Kant'a göre bu yetilerin nesnenin kuruluşuna katkıları bir fiil üzerinden anlaşılabilir. Yani nesne "ben"in kendinlik (Apperzeption) bilincinin fiiline bağlı olarak muhayyilenin sentezleme sürecinde düşüncenin konusu haline gelir. Ona göre bu fiilin kendinde varlığı olan bir özneye ya da faile atfedilebilmesinin imkânından bahsedilemediği gibi bu yetilerin işlevleri de temelde kurallara indirgenebilir. (Keller, 2004, pp.22) Ayrıca bu kuralların ait olduğu yetiler ile amprik temsillerin kaynağında var olan yeti birbirine indirgenemez. Yani amprik temsillerin varlığı sentezi yapan muhayyileye ya da senteze birlik veren müdrikeye bağlı değildir. $\mathrm{Bu}$ nedenle Kant'a göre ne temas edilen amprik temsiller ne de muhayyile ve müdrike aracılığıyla kurulan nesnenin kendinde bir varlığından bahsedilemez. Bir de amprik temsiller zaman ve mekan formuna bürünerek tezahür ettikleri için de tezahür etmemiş hallerinden bahsetme imkanı yoktur. (Broad, 1978, pp.54) Bu nedenle de tezahür edenin kaynağında ne tür bir varlık alanı olduğu noktasında herhangi bir fikir ileri sürmenin doğru olmadığını düşünür. Düşüncenin kendisine temas ederek kurduğu temsiller hissetme yetisinin formu olan zaman ve mekândan bağımsız olamazlar. Duyusal temsiller özneye bağlı olarak şekillenmekte ise de kaynağında başka bir varlık alanı olduğu için onlar hakkında kuşatıcı bir yargiya varmak zordur (Kant, 1993, s. A47).

Daha önce ifade edildiği üzere Kant'a göre amprik nesnenin kuruluşunun zemininde olan kuralların kendinde bir varlık alanı hakkında bilgi verebildikleri söylenemez. Ona göre örneğin matematiğin temelinde var olan sayı ve sayıların arasındaki öncelik ve sonralık bağıntısının bize metafizik yapabilme açısından zemin olmalarından da bahsedilemez. Sayılar arasındaki öncelik ve sonralık hissetme yetisinin formu olan zamandan elde edilir. Müdrikenin birlik vermesine bağlı olarak muhayyile 
saf görüde sayıyı inşa etmektedir. Kant'a göre sayı sentezlenmeden herhangi bir şekilde nesnenin kuruluşundan bahsetmek mümkün değildir. $\mathrm{Bu}$ anlamda sayının inşası diğer amprik nesnenin kuruluşunun zemininde Kant, saf temsiller olan müdrikenin kavramlarının amprik temsillere ilişkilenip nesnenin inşa edilebilmesi için bu iki yeti arasında üçüncü bir yeti olan muhayyileye ihtiyaç duyulduğunu ifade eder. Ona göre muhayyile sentezleme faaliyetinde bulunan bir yeti olması hasebiyle müdrikeden kurallarını alsa da bu kuralları kendisine ait olan şemalar aracılığ ile sentezi gerçekleştirir (Kant, 1993, s. A101). Nicelik şeması saf görü aracılığı ile sayı imgesinin inşasını mümkün kılar. Bu nedenle matematiğin yetiler aracıllğıyla kurulan bir saf zaman imgesine temelde dayandığını söylemek gerekir.

Yukarıda zikredilen nedenlerden dolayı Kant hem amprik temsilleri hem de sayıyı kendinde varlık alanına ait olarak görmenin doğru olmadığını düşünür. Yetilerin varlığına ve işleyişine bağlı olan sayı ve amprik temsillerin başka bir varlık alanına düşünce üzerinden temas etmeye zemin olmaları mümkün değildir. Amprik nesnenin kuruluşunun zemininde var olan bu iki unsurun düşünsel alana ait olmadığı fikri metafiziksel bilginin imkanını yok eder. Ayrıca nesnenin kuruluşunda temel olan bu iki unsurun diskurif yargı sürecinden bağımsızlığı da metafizik bilginin imkanını engel bir durum arz eder. Kant'a göre nesneyi sayı ve amprik temsiller üzerinden kuran fiil ile bunları belli kavramlar altında düşünen fiil arasında ayrım yapılmalıdır. Bu da doğal nesnelerin metafiziksel nedenler üzerinden açıklanmasının imkanını yok eder. Yani nesneyi belirleyen ile belli kavramlar altında tutan düşünme faaliyetini birbirinden ayırmak gerekir. Nesneyi amprik temsillere bağlı olarak kuran düşünme faaliyeti müdrikenin birlik verme faaliyetine bağlı gerçekleşiyor iken daha üst koşulsuz birlik verme süreçleri ise aklın muhakeme faaliyetine tabi gerçekleşmektedir. Akıl müdrikenin refleksif yargı süreçlerine bağlı olarak birlik kazandırdığı amprik kavramları daha üst birlik altına alma olan düşünme faaliyetini gerçekleştirmektedir. Akıl eğer müdrikenin kurduğu amprik nesneyi en üst koşul altına alabilirse nesnenin tam belirlenimine ulaşmış olacaktır. Böylece de nesne ile koşulsuz birlik arasında bir nedensellik düşünebilme imkanı elde etmiş olacaktır. Bu da amprik nesnenin koşulsuz ile ilişki içerisinde açıklanabilmesine zemin sağlayacağı için duyusal dünyanın nihai bir açıklanması 
elde edilecektir. Ona göre muhakeme faaliyeti nihai birliğini üç us ideası üzerinden kazandığı iddia edilse de bu birlik öznel olduğu için o öznel idealar üzerinden nesne hakkında geçerli bir nedensellik ortaya konması mümkün değildir (Kant, 1993, s. A309-B366).

Kant bu üç us ideasının ampirik nesne ile ilişkisi kurucu olmaktan ziyade düzenleyici bir durum arz ettiğini düşünür. Ona göre akıl en üst birlik altına alma ya da en üst koşullar altında düşünme yetisi olması nedeniyle müdrikede meydana gelen kavramsal çokluğa birlik verme ya da düzen verme yetisi olarak görülmelidir. Fakat işleyişi daha çok mantıksal kurallara göre gerçekleştiği için akıl yetisinin kurallarının doğa için zorunlu ve evrensel yasalar gerektiği söylenemez. Oysa kaynağı Platon'a kadar giden klasik metafiziğge göre aklın kavramlar ve kavramlar arasında kurduğu muhakeme faaliyetleri duyusal dünyadan bağımsız varlık hakkında genel geçer yasalar kurma olarak görülürdü. Akıl, müdrikenin hissetme yetisinden elde ettiği amprik temsillere birlik vermesi sonucunda ürettiği kavramlara bağlı bir işlevinin olduğu da düşünülmezdi. Bundan ziyade aklın saf bir görüsü olduğu ve bu kavramlara düzenleyiş kazandırmasının altında bu yattığı düşünülürdü.

Muhakeme faaliyetinin koşulsuza dayanarak fiilini gerçekleştirmesi gerektiği düşüncesi bu üç akıl ideasının gerçek olduğu ve doğa nesnelerinin bunlar üzerinden kavranması gerektiği fikrine kaynaklık ettiği gibi bu üç us ideası hakkında da genel geçer yargılarda bulunabileceği yanılgisına da sebep olmuştur. Kant'a göre bu üç ideadan biri olan ruh ideası ile ilgili olarak yapılan çıkarsamalar paraloji olmak durumundadırlar (Kant, 1993, s. B381). Yani teorik bilgi alanını sınırlarını aştığı için bu tür çıkarımlar aşkınsaldırlar. Ona göre bu çıkarımlar biçim itibariyle yanlış olmasalar da içerik olarak bahsettikleri nesne hakkında bilgi elde etme imkanımız olmadığı için yanılsama içerirler. Bu çıkarımların yanılsama içermesinin diğer bir sebebi de ruh hakkında çıkarım sağlayan kavramların duyusal alana uygulanma dışında herhangi bir işlevlerinin olmamasıdır. Amprik temsillerin hakkında anlamlı bir şekilde konuşabilmemizi sağlayan bu saf kavramların hissetme yetisinde temsilleri ile karşılaşmadığımız ruh gibi aşkınsal nesnelere uygulanması yanılsamaya neden olmaktadır. Oysa doğa hakkında böyle bir nesne üzerinden yasa tespiti mümkün olmadığı gibi bu tür aşkınsal nesneler hakkında genel geçer çıkarım ya da tespitler de bulunulamaz (Kant, 1993, s. B383). 


\section{Platon'un Kebes'in İtirazlarına Cevabı}

Kant'in ruh ve canlılık hakkındaki fikirlerinin Kebes'in savunduklarına benzediği düşünüldüğünde Platon'un Kebes'in itirazlarına verdiği cevapların ele alınması önemli hale gelmektedir. Kant'ın ruhun ve canlılığın oluş ve bozuluşa tabi olduğunu savunması daha önceki zamanlarda Platon'un ruhun oluş ve bozuluşa tabi olmadığına dair ortaya koyduğu kanıtlamaları açısından ele alınmasını anlamlı hale getirmektedir. $\mathrm{Bu}$ durum hareket (kinesis) meselesine yaklaşımın ruhun ölümsüzlüğünü kabul edip etmemenin temel noktasını oluşturduğu açık hale getirir. Platon'un yaklaşımını bu itibarla ele almak Kant'ın eleştirilerini anlamayı ve sınırlarını kavramayı sağlayacağı açıktır. Ayrıca Platon'un ruhun ölümsüzlügüne dair kanıtlarının Kant'ın eleştirilerine ne düzeyde cevap olduğu ve hangi noktalarda yetersiz kaldığını ortaya çıaracaktır.

Kebes'in itirazlarına Platon, oluşun ve bozuluşun mahiyetini açılama ile cevap vermeye çalışır. Ona göre ister amprik isterse de matematiksel nesnelerin nasıl var oldukları anlaşılmadan bu meselenin çözümü mümkün değildir. Bu anlamda Platon'a göre amprik dünyanın ya da matematiksel nesnelerin bir araya gelme ve ayrılma üzerinden var olduklarının savunulması mümkün değildir. Ona göre matematiksel nesnelerin varlığ 1 ne bir araya gelme ile ne de birbirinden ayrılmaya ile açıklanamaz. Çünkü herhangi bir şeyin varlık nedeni eğer bir araya gelme ise birbirinden ayrılma üzerinde de varlığa geldiklerini kabul etmek doğru değildir. Mesela "bir"in "bir"e eklenmesi ile eğer "iki" meydana geliyor ise "iki" den "bir"i meydana getirebilmek için bu defa ayırmak gerekiyor." İki"yi meydana getiren ilke ile "bir"i meydana getiren ilkenin birbirinden farklı olması matematiksel nesnelerin sadece bir araya gelme ya da birbirinden ayrışma üzerinden açıklanmasının mümkün olmadığını gösterir. Bu nedenle ona göre matematiksel sayıların faklılığını ve çokluğu kendinde büyüklük ve küçüklük üzerinden açılanmalıdır ki sayıların varlığa gelişinin nedeni de budur. Yani ona göre "bir"den sonra "iki" nin gelmesi ya da sayıların ardardalığı kendinde büyük ve küçüklük üzerinden kavranmalıdır. Herhangi bir sayıyı diğerinden ayıran ve sayıların ardardalığını sağlayan şey en temelde kendinde büyüklük ve küçüklüktür. Nesnelerin ya da insanların nicelik olarak farklılıklarını da eklenme ve 
çıkarma ile anlamak doğru değildir. İnsanların birbirinden farklı büyüklükte olmaları kendinde büyük ve kendinde küçüklükten pay almalarıdır. Platon'a göre bir insanın diğer insandan farklı boyda olması niceliksel eklenmeye dayalı olan şu miktarda onu geçti demek doğru değildir. Böyle söylendiğinde insanlar ya da nesneler arasındaki ebat farklılığın sanki eklenme ve çıarmadan kaynaklı olduğu zannı oluşur. Ona göre bu nedenle matematiksel sayıların varlığının bir araya gelme ve ayrışma ile açıklanması doğru değildir (Platon, 2015, s.105).

Sokrates: Yine büyük şeyler, büyüklüğ̈̈n sayesinde büyük, daha büyükler daha büyüktür. Küçük şeyler de kendinde kü̧̈ük şeyler sayesinde küçük olur. Bundan sonra bir insanın diğerinden bir kafa boyu uzun olduğu söylendiğinde ya da küçük olanın o kadar küçük olduğu söylendiğinde bunu kabul etmeyeceksin. Hatta buna itiraz ederek şöyle diyeceksin: bir şeyden büyük olan her şey, büyüklüğ̈̈n kendisinden dolayı büyüktür. Onun kendisini büyük yapan, bu büyüklüktür. Aynı durum küçüklük için de geçerlidir (Platon, 2015, s.105).

Sayılar arasında oluşan bazı niteliksel durumlar var ki Platon'a göre bunların varlığının sayıların birbirine eklenmesi ve çıkarılması ile açıklanması mümkün değildir. Örneğin ona göre sayıların aldığı teklik ve çiftlik gibi niteliksel farklılıkların ekleme ve çıarma sürecine tabi olduklarını söylenmesi doğru değildir. Örneğin üç sayısı teklik özelliğine sahip olduğu için tekliğe karşıt bir şeyle birlikte asla varlığını devam ettiremez. Yani ona göre teklik üçle özdeş olmasa da onun mahiyetini meydana getirdiği için tekliğin karşıtı çiftlikle birlikte varlığını devam ettirememektedir. Platon'a göre sayıların birbirleri ile ilişkileri belli zorunlu kurallar içinde gerçekleşmektedir. Yani sayıların varlığa gelişi eğer bir araya gelme ve ayrı̧̧ma ile açıklanabilse bu teklik ve çiftliğin neden bazı sayıların varlığı için zorunlu olduğu izahı zor hale gelebilir. Ekleme ve çıkarmayı önceleyecek şekilde çiftlik ve teklik bazı sayıların mahiyetini oluşturan zorunlu bir nitelik olduğu olduğu dikkate alındığında sayıların varlığa gelişinden bahsedilemeyeceği açıtır.

Platon'a göre nesnelerdeki niteliksel farklılıklar da bir araya gelme ve ayrışma üzerinden açıklanamaz. Örneğin sıcaklık ve soğukluk birbirlerine karşıt olan iki niteliktir. Bu iki niteliğin birbirine karşıt olması nesnenin varlığını önceler. Nesnenin ne tür bir formda ortaya çıkacağı bu niteliksel karşıtların birbirine göre durumuna bağlıdır. Yani Platon'a göre karın mahiyetine sıcaklık girmez. Bu nedenle her ne zaman sıcaklık geldiğinde 
kar varlığını devam ettiremez. Yani Platon'a göre duyusal nesne karşıt niteliklerden birini alarak varlık kazanır. Her ne zaman nesneyi var eden niteliğin karşıtı gelirse varlığı önceki niteliğe bağlı olduğu için söz konusu nesne varlığını devam ettiremez. Nesnedeki karşıtların var oluşu da bir araya gelme ya da ayrışma ile açıklanamaz (Platon, 2015, s. 109).

Platon'a göre nesnenin varlığı kendinde bir varlık (yani değişim ve harekete tabi olmayan) alanına tabidir. Kendinde varlığı olanlardan pay alarak amprik nesneler varlık kazanırlar. Bu nedenle de her şeyin varlığ1 ancak onun iyi ile ilişkisinden anlaşılabilir. İyi ile ilişkisi olmaksızın herhangi bir şeyin varlığından bahsedilemeyeceği gibi etrafımızdaki nesnelerin nasıl var olduklarının doğru açılanmasının da verilmesinin bir imkanı da yoktur. Bu nedenle de Platon varlığa gelişi karşıtların ardarda gelmesi olarak anlamaktadır. Ona göre karşıtların nesnede var olmasını doğadaki unsurların birbirine karışması veya ayrışması üzerinden açıklanması doğru değildir. Çünkü eğer nesnenin varlığı karşıtların birini alması ve nesnedeki değişim de diğer karşıtın gelmesi ile açıklanacaksa bu karşıtlardan bağımsız olarak nesnenin nasıl var olduğu açıklanamaz hale gelecektir. Çünkü karşıtlar bir arada bulunamaz iken karşıtları alan nesne karşıtlardan biri gidip diğeri geldiğinde (nesnenin mahiyetini oluşturmayan nitelikler kastedilmektedir) bile varlığını devam ettirebilmektedir. Yani değişim ve oluşum sırasında var olanlar geri dönülemez bir yokluğun içine girmemektedirler. Bilakis biteviye bir şekilde doğada karşıt niteliklerin birbirinin yerini aldığı bir durum mevcuttur. Ayrıca karşıtların belli bir nesne de olmaksızın kendinde hallerinde nasıl var oldukları da karışım ve ayrışım üzerinden açılanamaz. Sıcaklık veya soğukluk gibi nitelikler, unsurların bir araya gelmesi veya karışımından meydana gelmezler. Bu nedenle de karşıtların bizatihi varlıkları ya da bu karşıtların belli bir nesnede bulunması hareket üzerinden izah edilemez (Platon, 2015, s. 110).

Platona göre hareket ve değişim kendinde var olana tabi olarak anlaşılmalıdır. Çünkü harekete kaynaklık eden ne sayı ne de niteliksel karşıtlıklar bir araya gelme ve ayrışma üzerinden açıklanamaz. Çünkü eğer hareket ve değişim karşıtlıkların varlığını açıklayabilseydi bunların birlikte nesnede var olabilmesinden bahsedebilmemiz gerekirdi. Oysa Platon'a göre karşıtlıklar aynı nesnede bir arada var olabildikleri 
düşünülemez. Çünkü karşıtlıklar birbirini varlık olarak dışlarlar ve herhangi bir şekilde bir nesneyi tanımlamak istediğimizde karşıtlıklardan birini kullanmak durumundayız. Karşıtlıkların bir aradalığı çelişmezlik ilkesine uygun olmadığı için var olmayı izah etmesi mümkün değildir. Gerçekliğin akliliğe uygun var olduğu ve değişim ile hareketin de çelişmezliğe ters olmadığı düşünüldüğünde var olanların karşıtları bir arada taşımamaları gerektiği kabul edilmelidir. Ayrıca değişimde ve hareket halinde olanın apaçıklı̆ı çelişmezlikle elde edilir. Eğer hareket ve oluş çelişmezlik ilkesine uygun olmayacak şekilde karşıtları bir arada taşıdığı kabul edilirse hareket ve oluşun akli bir izahının da verilmesi imkânsız olur. Bu nedenle Platon zaman ve hareketi karşıtların ardışıklığına indirgeyip ardardalıkta oluşan nitelikleri de kendinde varlık alanına ait olarak görmüştür. Böylece Platon'un duyusal gerçeğin zemininde olan hareket ve değişimi ve bu bağlamda zamanı ruhsal bir alanla ilişkilendirmiştir ve böylece var olanların ancak hareket ve değişeme tabi olmayanlar üzerinden açıklanabileceğini göstermeye çalışmıştır (Platon, 2015, s. 111-112).

Kant değişim ve hareketi zamana bağlı olarak yorumlar ve zamanın ve onda ortaya çıkan temsillerin kavramsal süreçlerden bağımsız olduğu fikrini savunur. Ona göre kavramlar aracılığı ile elde edilen bilginin zamanda ortaya çıkanı kuşatabilmesinden bahsedilemez. Bu nedenle kavramsal olan ile görüsel olanı ayırmak gerektiğini ve amprik kavramların geçerliliğinin görüye tabi kılınması gerektiği düşünür. Çünkü kavramsal olan analitik yollarla apaçıklaştırılıyor iken zamana ait olan ya da hareketin kendisi analitik bir yolla apaçı hale getirilmesinden bahsedilemez. Bu da beraberinde çelişmezlik üzerinden nesne kurma faaliyetinden bahsedilemeyeceği için nesne kurma faaliyetinin sentez üzerinden açılanmasını zorunlu kılmaktadır. Zaman ait olanı çelişmezlik ilkesi üzerinden kuşatamayacağımız ortaya çıktığında zamanda ortaya çıkan temsillerin kuruluşunun zemininde de çelişmezlik ilkesinin varlı̆̆ından bahsedilemez. Zamanda ortaya çıkan temsiller ardarda bir şekilde karşıtlık içermiş olsaydı karşıtlı̆̆ın ilkesi çelişmezlik ilkesi üzerinden zamanda ortaya çıanı kuşatmak ve aynı zamanda varlığın ilkesinin çelişmezlik olduğu söylenebilirdi. Bu nedenle Kant'a göre çelişmezlik ilkesi üzerinden neyin var olamayacağı bilinse bile zamanda neyin zuhur edeceğini tespit etmek mümkün değildir (Kant, 1993, s. B33). 
Kant'a göre mantıksal ilkelerden yola çıkarak hissetme yetisinde hangi amprik temsilin ortaya çıkacağının bilinmesi veya açıklanması verilemez. Ona göre mantığın ilkelerinin iş gördüğü düzey tam algı fiilinin verdiği birliğe bağlı olarak muhayyilenin sentezi sonrasında ortaya çıkan amprik kavramların belli yargılarla birlik altına alınması aşamasında ortaya çıkar. Yani hissetme yetisindeki temsiller muhayyile aracllı̆g ile sentezlenip amprik nesne inşası gerçekleştikten sonra sentezlenen nesnenin farklı açılardan kavramlar altına alınması sürecinde çelişmezlik ilkesi devreye girmektedir. Bu nedenle Kant'a göre zaman ve onda ortaya çıkanın amprik temsillerin hakkında genel geçer bilgiye ulaşmanın yolu akli ilkelerden geçmez. Bu nedenle ona göre amprik temsilere yönelip kendinin farkına varan "ben" tarafından algılanmadan önce zamanın ne tür bir fiil aracılığı ile var olduğunun açıklanabilmesi mümkün değildir. Kant zamanı ve onda ortaya çıkan temsillerin kaynağı hakkında herhangi bir açıklamanın verilemeyeceğinin düşündüğü için bunların varlığını müsellem kabul eder. Ona göre müdrikenin gerek saf kavramlar aracılığı ile gerçekleştirdiği sentezleme gerekse de amprik kavramlar aracılığı ile nesneyi farklı açılardan belirleme süreçleri zamana ve onda ortaya çıkan amprik temsillere bağlı olarak açıklanmalıdır (Kant, 1993, s. B51).

Kant matematiksel nesnelerin de kendinde bir varlığının olmadığını düşünür. Ona göre saf görüde muhayyile aracılığı ile tam algı (Apperzeption) tarafından matematiksel nesneler inşa edilmektedir Saf görüde inşa edilmeleri itibari ile sayıların kendinde bir varlıklarının olduğunu iddia etmek doğru değildir. Bu nedenle de zamanın akışının sayı üzerinden farkına varılması ya da zamanın sayı üzerinden gerçekliğinin kuşatılmasından bahsedilemez. Çünkü ona göre sayıların tabi olduğu öncelik ve sonralık saf görünün formu olan zamandan gelir. Sayıların inşasının zaman tarafından öncelenmesi matematiksel nesnelerin kendinde bir varlığının olduğunu iddia etmeye imkan bırakmaz (Kant, 1993, s. A41). Bu nedenle de zaman ve zamanda ortaya çıkan amprik temsillerin hakkında matematiksel nesneler aracılığı ile belli tespitler yapilamaz.

Platon sayıların bir inşa süreci içinde varlığa geldiklerini kabul etmez. Ona göre sayılar iyi ile ilişkileri içerisinde var olan duyusal varlıklardan ayrı bir varlık düzeyine aittirler. Ayrıca ona göre sayıların öncelik ve sonralığı zamandan gelmez. Bunun yerine sayıların ardardalığı kendinde 
büyüklük ve kendinde küçüklük aracılığı ile var olur. Ayrıca Platon'a göre sayıların inşa sürecine değil de kendinde bir varlık alemine ait olduğu fikri sayılar arasında var olan teklik ve çiftlik gibi karşıtlıklar dikkate alındığında daha açık hale gelir. Sayıları incelediğimizde onlarda belli zorunlu ilişkiler ya da kuralların olduğunu görürüz. Bu özellikler sayıları var kılan ve onlar olmaksızın sayıların olamayacağı bir durum sergilerler. Platon açısından bakıldığında sayıların inşa sürecinde var oldukları kabul edilirse bu özelliklerin nasıl var olduklarını söylemek mümkün değildir. Ona göre inşa sürecinde sayıların birbirine eklenmesi ve çıkarılması üzerinden belli işlemler gerçekleştirilebilir. Oysa sayıların varlığını açıklamada ne bir araya getirmenin ne de ayırmanın kendisini bir ilke olarak görmek mümkün değildir. Sayıların varlığı bunu önceleyecek şekilde kabul edilirse bu ekleme ve ayırma faaliyetinin nasıl mümkün olduğu açıklanabilir. Bu nedenle de ekleme ve ayırma faaliyetini önceleyecek şekilde sayıların belli özelliklerinin nasıl var olduğu önem kazanmaktadır ki bu özellikler sayıların varlığından ayrı da düşünülemez (Platon, 2015, s. 111-112).

Platon'a göre matematikte gerçekleştirdiğimiz işlemlerin açılanabilmesi için sayıların bu işlemleri önceleyecek şekilde varlığı kabul edilmelidir. Sayıların nasıl var oldukları meselesi de Platon'a göre ancak iyi ideası ile ilişki içerisinde düşünüldüğünde çözülebileceği söylenmelidir. Sayıların inşaya tabi olarak var olmadıkları dikkate alındığında onların amprik nesneler gibi oluş bozuluşa tabi olmadıkları fark edilir. Oluş bozuluşa tabi olmayan şeylerin kendinde bir varlığa sahip olmaları gerektiğine göre bunların varlığı ancak iyi olana göre düşünülebilir. Bu açılardan bakıldığında Kant'ın matematiksel nesneleri saf görüde inşaya indirgemesi sayıların ancak zaman formu altında bir araya getirme ve ayırma faaliyetinin sonucunda var oldukları anlamına gelir. Oysa Platon'a göre sayılar üzerinde yapılan her türlü ekleme ve ayırma işlemleri sayıların varlığının kabulünden sonra ancak gerçekleşebileceği söylenmelidir. Platon açısından bakıldığında ekleme ve ayırma faaliyetinin tabi olduğu sayılarda var olan çiftlik ve teklik gibi özelliklerin Kant tarafından tam bir açıklama verilemediğini söylenebilir. Çünkü Platon sayıların kendi varlıkları ve onlardaki bu özelliklerin bu tür işlemeleri öncelemesi gerektiğini düşünür. 
Platon'un, sayılardaki ardardalığın saf zaman görüsü üzerinden açıklanabileceğini de kabul etmesinden bahsedilemez. Ona göre sayı ve kendinde nitelikler olmaksızın amprik nesne var olamayacağı için zaman da bir şekilde sayı ve niteliklere bağlı olarak Demirgue fiili üzerinden açıklanmalıdır. Bu nedenle de Platon onları önceleyecek şekilde sayıların ya da niteliklerin kendisine tabi olduğu zamansal bir düzenin varlığını kabul etmez. Bu nedenle Kant açısından çözümsüz kalmış bir nokta, sayı ve temsillerin bilincinde olmaksızın zamanın farkında olmanın imkânı neye dayanmaktadır. Saf bir form olarak zamanın sayı ve temsillere önceliğinin olduğunu iddia etmek zamanın nasıl var olduğunun açıklanması verilmeden kabul edilmesi anlamına gelir ki Kant'ın ruhun var olmadığını iddia etmesinin geçersiz olduğu söylenebilir. Çünkü Platon'a göre ruhun kalıcılığının delaleti sayıların kendinde varlıkları ve niteliklerin duyusal dünyadan bağımsız var olduğunun gösterilebilmesidir. Ayrıca sayılar ve kendinde formların bilgisi de eğer zamana tabi olmaksızın anamnesiz (hatırlama) ile mümkün olabiliyorsa ruhun kendi farkına varma sürecinin zaman ve duyu ile ilişkili olmadığına da işarettir. Böylece ruhun kendilik bilinci onun bir ve iyi ile kurduğu ilişki üzerinden açıklanmalıdır ki bu ruhun ölümden sonra kalıcılı̆̆ 1 için yeterlidir.

\section{Sonuç}

Kant'a göre amprik nesnenin kuruluşu ve bu bağlamda zamanın varlığ ruhun oluştan ve bozuluştan bağımsız kendinlik bilinci (töz olmaklığı) üzerinden açıklanamaz. Ona göre amprik alandaki temsiller ve bu temsilleri kuşatan zaman, kendisinin bilincinde olandan bağımsız bir şekilde var olurlar. Klasik metafiziğin düşünmeyi töz olarak kabul edip amprik alanın varlığını bunun üzerinden açıklama girişimi sürekli başarısızlıkla sonuçlandığı için ruhun zamandan bağımsız kalıcılığını iddia etmek geçersizdir. Bu nedenle ona göre düşünme faaliyetinin faili olan apperzeption (tam algi) kendi bilincini zamandaki ve amprik temsillerdeki çokluğa bağlı bir şekilde elde eder. Saf görüdeki bu çokluğa yönelir ve muhayyile aracılığı ile sentezledikten sonra anlamlı bir şekilde nesnesinden bahsedebilir hale gelir. Nesnenin bu kuruluş sürecinde devrede olan kategoriler, anlamlı bir nesne şeklinde konuşulmasına ruhun kendisi hakkında da zemin olamazlar. Ona göre duyusal temsiller kendisi 
hakkında bilgi sahibi olamadığımız kendinde nesnenin hissetme yetisi üzerindeki etkisi nedeni ile var oldukları için bunların da zamandan bağımsız bir varlığından bahsedilebilmeleri ve böylece de kendinde varlık alanı için bir delalet olabilmeleri söz konusu olamaz. Ayrıca Kant sayıların saf görüde inşa edildiğini iddia etmektedir ki bu iddia temelde zaman aracılığı ile fark edilenden bağımsız bir varlık alanından bahsedebilmenin ya da onun hakkında konuşmanın geçersizliğini vurgulamaktadır.

Platon'a göre amprik nesnenin kuruluşunda var olan hem sayı hem de niteliklerin zamanın akış sürecine tabi bir şekilde var oldukları söylenemez. Ona göre sayılarda var olan bazı özellikler ve kurallar sayıların bir araya getirilmesi ve ayrıştırılmasından bağımsız bir şekilde onları öncelemektedir. Bu nedenle de oluş içerisinde var olan amprik nesneler gibi bunların da zamanın ardardalığına tabi olduklarını söylemek mümkün değildir. Çünkü ona göre zaman Demirgue'nin bir fiili olarak sayı ve kendinde nitelikler sayesinde mümkün olmaktadır. Yani ona göre sayıları zamana tabi olarak inşa edilen saf nesneler olarak görmek doğru değildir. Çünkü sayılar zamandaki ardardalıkla kazanamayacakları bazı kuralları ve özellikleri kendilerinde barındırmaktadırlar. Sayıların bu özelliklerinin onların varlığından ayrılamamasından dolayı zamanın ardardalığında bu kuralların olmamasından ya da aksinin mümkün olmasından bahsedilemez. Yani her şekilde zaman ve zamanda ortaya çıkanlar sayıdaki bu kurallara tabi bir şekilde zuhur edecekleri için Platon'a göre zamanın varlığını sayıları önceleyecek şekilde kabul etmek mümkün değildir.

Platon sayılar ve nitelikler aracılı̆g ile zamana tabi olan duyusal dünyadan bağımsız bir kendinde varlık alanından bahsedilme imkanı yaratmış olsa da değişime tabi olmayan ve farklılık içeren bu kendinde varlık alanına ait bu çoklukların nasıl olup ta var olduğunu ve kendinde iyi ile ilişkilerinin nasıl olduğunu açılanmadığ ifade edilebilir. Ölüm ile cezalandırılmış iken ziyaretine gelen öğrencilerine ruhun kalıcılığını göstermek anlamında sayının ve niteliklerin kendinde bir varlığ olduğunu göstermeye çalışmak kuşkusuz anlamlı gelebilir. Fakat ruhun amprik nesnelerden farklı olarak nasıl bir varlık alanına ait olduğunun açıklanması önemli olduğu gibi zamanda olanla ilişkisinin ne olduğunun açıklanabilmesi de Kant'ın eleştirilerine cevap verebilmekte daha güçlü 
bir zemin sağlayabilirdi. Yani Platon ruhun amprik dünyadaki oluş ve bozuluşa tabi olmadığı ortaya koymada belli kanıtlar ileri sürmüş olsa da ruhun zaman ve zamanda da var olanla ne tür bir ilişkisini olduğunu açıklama çabası yeterli olmadığı için sonraki süreçte Kant'ın eleştirilerine imkan verdiği söylenebilir 


\title{
EXTENDED ABSTRACT
}

\section{Kant's Criticism of The Claims Concerning The Immortality of Soul and Plato's Probable Answers in Phaidon}

\author{
Ahmet Uğurlu \\ Bolu Abant Izzet Baysal University
}

Kant thinks that one of the discussions which could not be somehow concluded throughout the history of thinking is the existence and immortality of the soul. According to him, this matter caused endless debates between two parties that constantly advocate their own ideas. He argues why such debates are yet to be concluded is mainly because the limits of human's theoretical knowledge could not be determined well. It is necessary to investigate and explore in depth the faculties on which our knowledge is based so that the limits of the knowledge that humankind can attain. Because he thinks that those points in which the sensory material is processed and transformed into knowledge are the faculties of human's soul. Failure to sufficiently explore the functions of faculties and what they contribute to knowledge has led to inextricable arguments.

According to Kant, sensory representations, which are the source of our knowledge, manifest themselves in the faculty of sensation. These representations come into appearance depending on time and space which are the the forms of the faculty of sensation. After sensory representations have taken the form of the faculty of sensation, they are synthesized into a particular unity by imagination and intellect, which are the other faculties of human's soul. Imagination synthesizes sensory representations through schemas in accordance with the unity of categories in intellect. While imagination reproduces representations according to the pure intuition of time and space, intellect allows these representations to be recognized in compliance with the concepts. Hence, according to him, knowledge results from the processes of imagination and intellect on representation. However, as the sensory material gains appearance in the 
form of time and space most basically, processes of imagination and intellect must take place in accordance with these forms. That is to say, knowledge becomes possible as a result of the processing of sensory representations depending on time and space. Therefore, Kant argues that knowledge of the soul becoming possible requires having sensory presentations of it. Since the soul is not an empirical object with sensory representations, it is not possible to say that it is an object resulting from synthetization.

It is accepted by everyone that the soul is not an empirical object formed through sensory representations. According to those who claim that knowledge on soul's existence is possible, knowledge of soul is not based on sensory experience. They suggest that the soul exists in itself. The source of knowledge on it must therefore be different from the sensory material. Knowledge of the soul is an intuition through which the objects of the realm of existence are cognized. Kant does not find this true and thinks that we do not have any intuition other than the pure intuition through which mathematical objects are built. As mathematical and empirical objects are built in compliance with the intuition of time and space in the pure intuition, whatever is known and experienced must be in accordance with what is mathematical. Thus, according to Kant, all intuitions of which existence is argued other than the pure intuition are invalid.

Plato thinks that we have the knowledge of pure thinking elements which are not subject to generation and corruption. He argues that interquality opposites as well as numbers are elements not subject to generation and corruption. According to him, numbers have properties that remain unchanged and does not exist through generation-corruption. Because, if numbers existed depending on confluence and divergence in time and space, they should not become extinct or should exist on with other properties, too, when they lost their certain properties. We see some numbers are odd, and others are even. Even numbers do not become odd and vice versa. Existence of numbers depending on such unchanging situations led Plato to the idea that these numbers are not subject to generationcorruption. According to him, numbers should be argued to exist by having a share of what is good in itself, not depending on confluence and divergence. 
Moreover, qualities which the existence of the sensory object is subject to exist by having certain unchanging situations. He thinks that existence of these empirical objects depending on taking up these properties connotes a spiritual being independent from the sensory world. An example of this is the existence of snow depends of being wet and white. In addition, how death and life do not unite in an object shows that qualities do not have mandatory properties which are not subject to change in themselves. In other words, qualities exist in the object depending on the fact that certain opposites cannot unite. If an object bears a quality compulsorily, the object ceases to exist when its opposite appears. This indicates that qualities are not subject to confluence and divergence.

According to Kant, numbers do not have a realm of existence in themselves. What we call numbers are pure objects built by intellect via imagination in the pure intuition. Thus, arguing that there is evidence on the existence of the soul through numbers or suggesting ideas on the soul through these is not right. In this sense, what Kant needs to be asked is "How do the numbers and the opposites in the qualities bringing the object into existence exist?" Why do certain qualities become mandatory for the existence of certain objects? Will it be possible to mention the possibility of confluence of aliveness and death when everything is reduced to time and space?" One can say that such questions produce issues difficult to be solved in terms of Kant's metaphysics. As for Plato, criticism can be made through the numbers for which one cannot argue that they exist with opposites in mathematics. When it is determined that all situations in the object through opposition, it brings about challenges in exploring the existence of the soul through such way.

\section{Kaynakça / References}

Borad, C. D. (1978). Kant an introduction. London: Cambridge University Press.

Brook, A. (1994). Kant and mind. New York: Cambridge University Press.

Çitil, A. A. (2012). Matematik ve metafizik. İstanbul: Alfa Yayınları.

Dickerson, A. B. (2004). Kant on representation and objectivity. New York: Cambridge University Press. 
Friedman, M. (1992). Kant and the exact sciences. London: Harward University Press.

Guyer, P. (1987). Kant and claims of knowledge. New York: Cambridge University Press.

Keller, P. (2004). Kant and the demands of self-counsciousnes. New York: Cambridge University Press.

Hanna, R. (2001). Kant and foundations of analytic philosophy. New York: Oxford University Press.

Longuenesse, B. (2000). Kant and capacity to judge, (çev., C. T. Wolfe) New Jersey: Princeton University Press.

Melnick, A. (2009). Kant's theory of self. New York: Routledge Press.

Kant, I. (1993). Arı usun eleştirisi. (çev. A. Yardımlı), İstanbul: İdea yay.

Platon (2015). Phaidon (çev. F. Akderin). İstanbul: Say yay.

Temizkan, V. (2016). Platon'un Phaidon diyalogunda Anamnesis Kuramı. Felsefe ve Sosyal Bilimler Dergisi, 21, 217-230.

\section{Kaynakça Bilgisi / Citation Information}

Uğurlu, A. (2019). Kant'in ruhun ölümsüzlüğüne ilişkin görüşlere yönelik eleştirileri ve Phaidon diyaloğundan hareketle Platon'un bu eleştirelere verebileceği olası cevaplar.OPUS-Uluslararası Toplum Araştırmaları Dergisi,13(19), 2729-2756. DOI: 10.26466/opus.586864 